\title{
Complementation of Deletion and Insertion Mutants of TOL Plasmid pWW0: Regulatory Implications and Location of $x y l C$ Gene
}

\author{
By MICHAEL R. LEBENS AND PETER A. WILliams* \\ Department of Biochemistry and Soil Science, University College of North Wales, Bangor, \\ Gwynedd LL57 2UW, UK
}

(Received 14 June 1985)

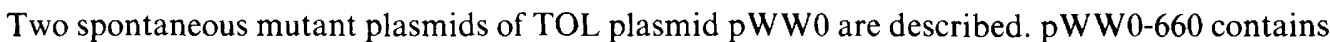
an $18 \mathrm{kbp}$ deletion of the entire $x y / C A B$ operon and pWW0-673 has a $3.4 \mathrm{kbp}$ insert in the operator-promoter (OP1) region of $x y l C A B$. In Pseudomonas putida hosts containing either plasmid, $m$-xylene was unable to act as a growth substrate or as an inducer of enzymes of the $x y l C A B$ or of the $x y l D L E G F$ operons. Complementation of these strains with a recombinant plasmid pWW0-3006 carrying the HindIII region D (HD) of pWW0 restored the $\mathrm{Mxy}^{+}$ phenotype and the ability of $m$-xylene to induce the $x y l D L E G F$ operon. The cloned HD region had no regulatory function but carried the OP1 region, the entire $x y l C$ structural gene and sufficient of $x y l A$ to support growth on $m$-xylene. $X y l C$ was more precisely located on a $1.9 \mathrm{kbp}$ Sall subclone of the HD region. Comparison of the roles of $m$-xylene and $m$-methylbenzyl alcohol as inducers shows they are not equivalent and that whereas $m$-xylene can induce only $x y l C A B, m$-methylbenzyl alcohol can induce both $x y l C A B$ and $x y l D L E G F$. The restoration of the induction of $x y l D L E G F$ by $m$-xylene is due to the presence of $x y l A$ on the recombinant pWW0-3006, converting $m$-xylene to $m$-methylbenzyl alcohol.

\section{INTRODUCTION}

The TOL plasmid pWW0 carried by Pseudomonas putida mt-2 (PaW1) specifies a set of inducible enzymes that catalyse the catabolism of toluene and $m$ - and $p$-xylenes. A model for the regulation of the pathway was proposed by Worsey et al. (1978). Genes for the enzymes of the upper part of the pathway form an operon, $x y l C A B$, the products of which convert the hydrocarbon substrates to corresponding carboxylic acids. A second operon, $x y l D L E G F$, codes for enzymes responsible for further degrading the carboxylic acids to acetaldehyde and pyruvate via meta cleavage of catechol derivatives (Fig. 1). It was proposed that expression of the pathway was controlled by two regulatory genes: $x y l R$ controls the expression of both operons in the presence of $m$-xylene or $m$-methylbenzyl alcohol (which have been used interchangeably as $x y l R$ coinducers) and $x y l S$ induces only the lower pathway in the presence of $m$-toluate.

Subsequent work on pWW0 and pTN2, an RP4 cointegrate plasmid carrying the pWW0 catabolic genes, has located most of the genes of the upper and lower pathways by molecular cloning and transposon mutagenesis (Franklin et al., 1981; Inouye et al., 1981 a; Harayama et al., 1984; Timmis et al., 1985) and demonstrated that $x y l R$ and $x y l S$ act as positive regulators (Franklin et al., 1981; Franklin \& Williams, 1980; Inouye et al., 1981 b; Nakazawa et al., 1980). Both regulatory genes have been located and cloned (Franklin et al., 1983; Inouye et al., 1981 b, 1983). Recombinant plasmids containing $x y l R$ and $x y l S$ were used to demonstrate that both are required for expression of the lower pathway when induced with $m$-xylene (Inouye et al., 1983).

Abbreviations: BADH, benzyl alcohol dehydrogenase; BZDH, benzaldehyde dehydrogenase; $\mathrm{C} 23 \mathrm{O}$, catechol 2,3-oxygenase; HMSH, 2-hydroxymuconic semialdehyde hydrolase; HMSD, 2-hydroxymuconic semialdehyde dehydrogenase. 

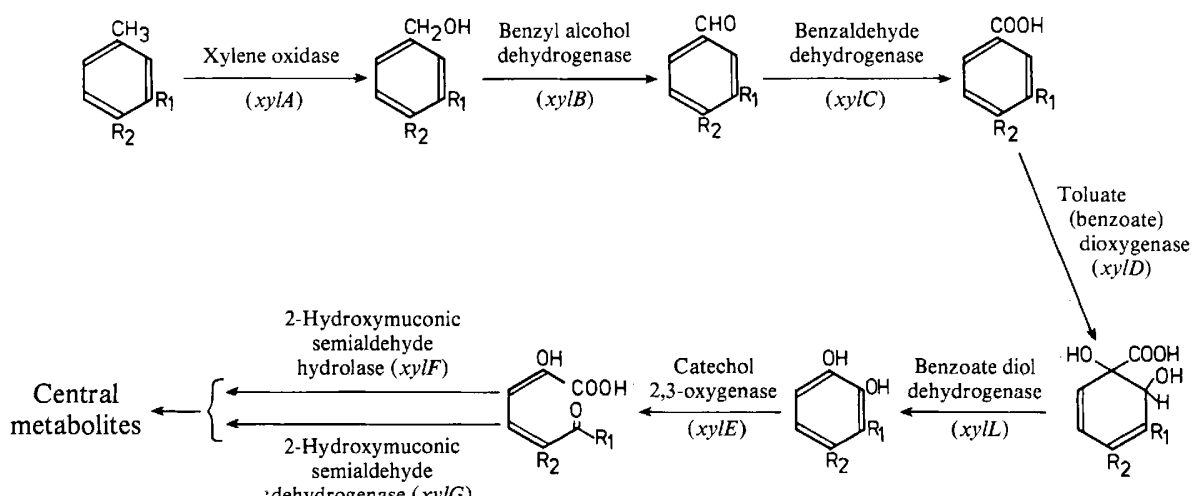

Fig. 1. Early enzymes of the TOL plasmid degradative pathway. The primary metabolites of the pathway are toluene $\left(\mathrm{R}_{1}=\mathrm{R}_{2}=\mathrm{H}\right)$, $m$-xylene $\left(\mathrm{R}_{1}=\mathrm{CH}_{3}, \mathrm{R}_{2}=\mathrm{H}\right)$ and $p$-xylene $\left(\mathrm{R}_{1}=\mathrm{H}, \mathrm{R}_{2}=\right.$ $\left.\mathrm{CH}_{3}\right) ; m$-toluate is the carboxylic acid metabolite of $m$-xylene.

It was also shown that $x y l S$ insertion mutants were unable to express the lower operon in the presence of $m$-methylbenzyl alcohol although the upper pathway was induced normally (Franklin et al., 1983). These results suggest that the regulation of the two pathways is not as straightforward as previously thought. The present work investigated the effect of cloned wildtype DNA on strains carrying derivatives of the TOL plasmid pWW0. Further evidence is presented that the $9.8 \mathrm{kbp} H$ indIII D fragment (HD) of pWW0 carries the operator-promoter regions for the upper pathway operon and the entire $x y l C$ gene, the position of which has been precisely mapped.

Evidence is also presented that sufficient of the $x y l A$ gene resides on HD to allow expression of xylene oxidase. The phenotypes of the complemented and uncomplemented strains carrying mutant plasmids suggested that, contrary to the currently held model, $m$-xylene is unable to induce the lower pathway operon, even when both $x y l R$ and $x y l S$ are functional, and that the product of the upper pathway responsible for induction of the lower pathway is $m$-methylbenzyl alcohol.

\section{METHODS}

Bacterial strains and plasmids. The Pseudomonas putida strains used in this study are shown in Table 1 with their plasmid complements and relevant phenotypes. The Escherichia coli strains were all derived from strain PM191, a rec $A$ derivative of strain $\mathrm{C} 600$, which was used as recipient in all transformations.

The different mutant derivatives of the TOL plasmid pWW0 were originally isolated and mapped by Jeenes (1982).

The vectors used for cloning pWW0 DNA were the broad host-range plasmid pKT230 (Bagdasarian et al., 1981), which has a number of unique restriction endonuclease recognition sites in both the kanamycin and streptomycin resistance genes, and pBR325 (Bolivar, 1978) which carries genes for resistance to ampicillin, tetracycline and chloramphenicol.

Plasmid purification. The TOL plasmid and its derivatives were extracted using the sucrose gradient method of Wheatcroft \& Williams (1981). Vector and recombinant plasmids were extracted from $E$. coli strains by a cleared lysate procedure followed by $\mathrm{CsCl}$ gradient centrifugation (Guerry et al., 1973).

Recombinant plasmids were rapidly extracted from strains of both E. coli and Pseudomonas by the method of Holmes \& Quigley (1981).

Restriction endonuclease digestion of DNA and agarose gel electrophoresis. All restriction endonuclease digestions were done in O'Farrell T4 DNA polymerase buffer (Maniatis et al., 1982). All restriction endonucleases were obtained from BRL or NBL Enzymes.

Digested DNA was analysed by agarose gel electrophoresis as previously described (Jeenes et al., 1982). Specific DNA fragments were eluted from agarose gels by the method of Girvitz et al. (1980).

Cloning of specific DNA fragments from $\mathrm{pWWO}$ and its derivatives. The HD fragment from $\mathrm{pWW} 0$ was obtained from a shotgun cloning experiment in which total pWW0 DNA was digested with HindIII and ligated into the 
Table 1. Bacterial strains and plasmids

\begin{tabular}{|c|c|c|c|}
\hline Strain & Plasmid & Plasmid phenotype* & Notes and references \\
\hline Pseudomonas putida $\mathrm{mt}-2$ (PaW1) & pWW0 & $\mathrm{Mxy}^{+} \mathrm{Mtol}^{+}$ & \\
\hline PaW 130 & - & - & $\begin{array}{l}\text { Plasmid-free derivative of } \\
\text { PaWl, Rif }\end{array}$ \\
\hline PaW660 & pWW0-660 & $\mathrm{Mxy}^{-} \mathrm{Mtol}^{+}$ & Jeenes $(1982)$ \\
\hline $\mathrm{PaW} 673$ & pWW0-673 & $\mathrm{Mxy}^{-} \mathrm{Mtol}^{+}$ & Jeenes (1982) \\
\hline $\mathrm{PaW} 790$ & pWW0-3006 & $\mathrm{Sm}^{\mathrm{r}} \mathrm{Km}^{\mathrm{s}}$ & This study \\
\hline PaW791 & pWW0-3024 & $\mathrm{Sm}^{\mathrm{r}} \mathrm{Km}^{\mathrm{s}}$ & This study \\
\hline PaW796 & $\begin{array}{l}\text { pWW0-673, } \\
\text { pWW0-3006 }\end{array}$ & $\mathrm{Mxy}^{+} \mathrm{Mtol}^{+}$ & This study \\
\hline $\mathrm{PaW} 820$ & $\begin{array}{l}\text { pWW0-660, } \\
\text { pWW0-3006 }\end{array}$ & $\mathrm{Mxy}^{+} \mathrm{Mtol}^{+}$ & This study \\
\hline PaW825 & $\begin{array}{l}\text { pWW0-660, } \\
\text { pWW0-3024 }\end{array}$ & $\mathrm{Mxy}^{+} \mathrm{Mtol}^{+}$ & This study \\
\hline \multirow[t]{10}{*}{ Escherichia coli $\mathrm{PM} 191$} & - & - & $\begin{array}{l}\text { Thi }^{-} \text {Th }^{r} \text { Leu }^{-} \text {RecA; } \\
\text { N. J. Grinter (Searle, High } \\
\text { Wycombe, UK) }\end{array}$ \\
\hline & pWW0-3006 & $\mathrm{Sm}^{r} \mathrm{Km}^{s}$ & HD in pK T230, this study \\
\hline & pWW0-3024 & $\mathrm{Sm}^{\mathrm{r}} \mathrm{Km}^{\mathrm{s}}$ & $\begin{array}{l}\text { SmaI/Hind III subclone of HD; } \\
\text { this study }\end{array}$ \\
\hline & pWW0-3001 & $\mathrm{Sm}^{r} \mathrm{Km}^{\mathrm{s}}$ & $\mathrm{XF}$ in pKT230; this study \\
\hline & pWW0-3002 & $\mathrm{Sm}^{r} \mathrm{Km}^{\mathrm{s}}$ & $\mathrm{XG}$ in pKT230; this study \\
\hline & pWW0-3010 & $\mathrm{Sm}^{\mathrm{r}} \mathrm{Km}^{\mathrm{s}}$ & $\begin{array}{l}\text { XF fragment with } 3.4 \mathrm{kbp} \\
\text { insert from pWW0-673 in } \\
\text { pKT230; this study }\end{array}$ \\
\hline & pWW0-3026 & $\mathrm{Sm}^{r} \mathrm{Km}^{\mathrm{s}}$ & $\begin{array}{l}\text { Smal/BamHI subclone of HD } \\
\text { in pKT } 230 ; \text { this study }\end{array}$ \\
\hline & pWW0-3027 & $\mathrm{Ap}^{r} \mathrm{Cm}^{r} \mathrm{Tc}^{\mathrm{s}}$ & $\begin{array}{l}\text { SalI subclone of XG in } \\
\text { pBR325; this study }\end{array}$ \\
\hline & pWW0-3028 & $A p^{r} \mathrm{Cm}^{r} T c^{s}$ & $\begin{array}{l}\text { Sall subclone of XG in } \\
\text { pBR325, opposite orientation } \\
\text { to pWW } 0-3027\end{array}$ \\
\hline & pWW0-3029 & $\mathrm{Sm}^{r} \mathrm{Km}^{\mathrm{s}}$ & $\begin{array}{l}\text { Xhol/BamHI subclone of XG in } \\
\text { pKT230; this study }\end{array}$ \\
\hline
\end{tabular}

* $\mathrm{Mxy}^{+}$and $\mathrm{Mtol}^{+}$denote the ability to grow on $m$-xylene and $m$-toluate, respectively, as sole source of carbon and energy; $\mathrm{Sm}^{r}, \mathrm{Km}^{r}, \mathrm{Cm}^{r}$ and $\mathrm{Tc}^{r}$ denote resistance to streptomycin, kanamycin, carbenicillin and tetracycline, respectively.

HindIII site of pKT230. Ligations were done with T4 DNA ligase obtained from BRL under conditions recommended by the suppliers. Ligated DNA was transformed into $\mathrm{CaCl}_{2}$-treated cells of $E$. coli strain PM191 and transformants were selected on nutrient agar plates containing streptomycin $\left(15 \mu \mathrm{g} \mathrm{ml}^{-1}\right)$. Colonies containing recombinant plasmids were detected by their sensitivity to kanamycin $\left(15 \mu \mathrm{g} \mathrm{ml}^{-1}\right)$ which was determined by replica picking of single colonies.

Strains containing recombinant plasmids were screened by small-scale rapid plasmid extraction followed by restriction endonuclease analysis in which inserts were compared with HindIII digests of pWW0 DNA. In this way the plasmid pWW0-3006 was isolated which contained the HD fragment of pWW0 in pKT230.

An identical procedure was used to obtain the XhoI digestion fragments XF and XG of pWW0 in the

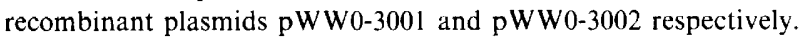

The $X h o I$ fragment from the mutant plasmid pWW0-673 which contained insert DNA was cloned into pKT230 after electroelution from agarose gels. The various subclones were produced by restriction of the appropriate recombinant DNA with the required enzymes and religation either directly or in the presence of an alternative vector. The fragments contained in the different recombinant plasmids generated in this study are shown in Fig. 2.

Matings and complementation analysis. All conjugation experiments were done non-quantitatively by patching donor and recipient bacteria onto a nutrient agar plate and incubating at $30^{\circ} \mathrm{C}$ overnight in the case of Pseudomonas strains or at $37^{\circ} \mathrm{C}$ for $4 \mathrm{~h}$ in the case of $E$. coli. Cells from the mixed colony were then suspended in $0.5 \mathrm{ml} 0.1 \mathrm{M}$-sodium phosphate buffer $\mathrm{pH} 7.5$ and dilutions were spread onto appropriate selective agar plates. Using RP4, the recombinant plasmids pWW0-3006 and pWW0-3024 were mobilized into PaW130, a plasmidfree Rif derivative of $\mathrm{PaWl}$. The resulting transconjugant strains were $\mathrm{PaW} 790$ and $\mathrm{PaW} 791$ which were subsequently used as recipients for the mutant TOL plasmid pWW0-660 (Table 1). 


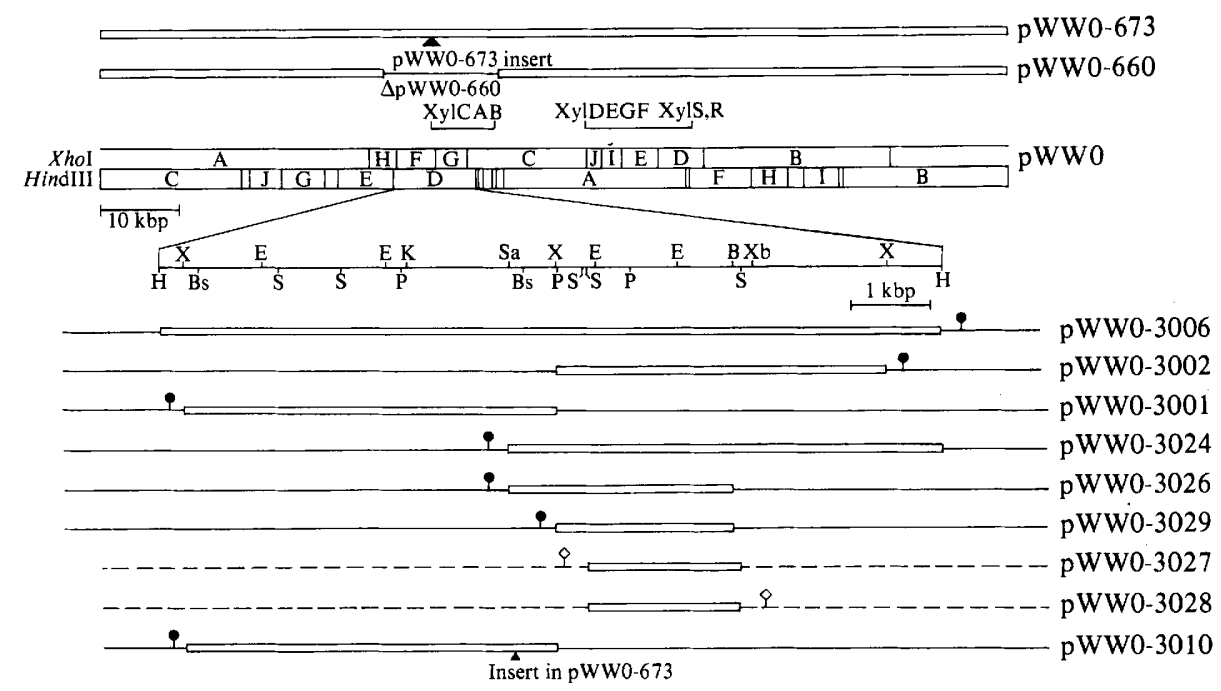

Fig. 2. Restriction map of pWW0 and its derivative plasmids. The expanded region in the lower half shows a detailed map of the HD region and the subclones generated during this study. The open rectangles show the pWW0 DNA, the solid line pKT230 and the broken line pBR325; 9 marks the kanamycin promoter of pKT230 reading towards the inserts and $\hat{P}$ marks the tetracycline promoter of pBR325 in the same orientation. Restriction enzyme sites are denoted: B, Bam HI; Bs, Bst EII ; K, KpnI; P, PstI; S, SalI; Sa, SmaI; X, XhoI; Xb, XbaI.

Enzyme assays and preparation of cell extracts. Enzymes assayed as being representative of the upper pathway were benzyl alcohol dehydrogenase (BADH) and benzaldehyde dehydrogenase (BZDH). Representative enzymes of the lower pathway were catechol 2,3-oxygenase (C23O), 2-hydroxymuconic semialdehyde hydrolase (HMSH) and 2-hydroxymuconic semialdehyde dehydrogenase (HMSD). Cells were grown up in the presence of appropriate inducers and cell extracts were prepared according to previously described procedures (Jeenes et al., 1982).

Enzymes were assayed by previously described methods (Sala-Trepat \& Evans, 1971; Williams \& Murray, 1974; Worsey \& Williams, 1975). All assays were done at least twice on different batches of cells, and the values quoted are the mean. The variation was within $\pm 20 \%$ of the quoted value.

Xylene oxidase was assayed by measurement of the stimulation of oxygen uptake in a Clark oxygen electrode in response to addition of $m$-xylene.

Protein was determined by the Biuret method.

\section{RESULTS}

\section{Characterization of $p W W 0-660$ and $p W W 0-673$ and the mapping of the $H D$ region of $p W W 0$}

The mutant plasmids pWW0-660 and pWW0-673 both arose spontaneously during studies in which pWW0 was transferred into the chlorobenzoate-degrading strain Pseudomonas sp. B13 (Jeenes, 1982). When transferred back into a plasmid-free derivative of $P$. putida $\mathrm{mt}-2$, both produced a similar phenotype and biochemical characteristics: host strains were $\mathrm{Mxy}^{-} \mathrm{Mtol}^{+}$, expressed none of the catabolic enzymes when induced with $m$-xylene but expressed the lower operon enzymes when induced with $m$-toluate (Jeenes, 1982). Restriction analysis of their plasmids showed distinct differences. pWW0-660 contained a deletion of about $18 \mathrm{kbp}$ which covered all the upper operon genes but did not affect the lower operon or either of the regulatory genes $x y l R$ or $x y l S$. pWW $0-673$ on the other hand contained a $3.4 \mathrm{kbp}$ insertion in the HindIII D fragment (HD). The location of this was accurately mapped by restriction analysis of cloned restriction fragments of $\mathrm{pWW} 0$ and of the $X$ hoI fragment from pWW0-673 containing the insert (Fig. 3). The map of the HD fragment of pWW0 was constructed by restriction analysis of cloned HD and $X$ hoI $F$ and G fragments (Fig. 2).

According to the mapping data of Inouye et al. $(1983,1984)$, the insert in pWW0-673 is in the operator-promoter region (OP1) of the upper operon. As far as the present data allow, it is 


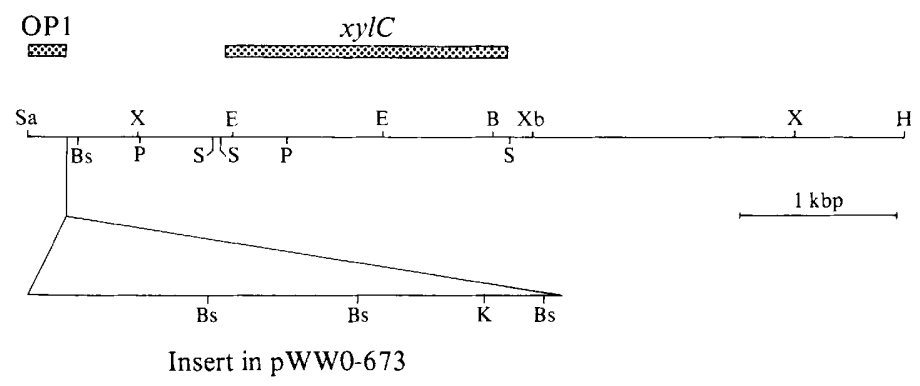

Fig. 3. SmaI/HindIII subclone of the HD region of $\mathrm{pWW} 0$ showing the location of the insertion in pWW0-673, the position of OP1 and the $x y l C$ gene.

identical in nature and location to the inserts in the previously described plasmids pWW0-2001 and pWW0-2023 (Jeenes \& Williams, 1982). The origin of the insert has been discussed elsewhere by Lehrbach et al. (1983).

\section{Complementation of mutant plasmids with recombinant plasmids $p W W 0-3006$ and $p W W 0-3024$}

When pWW0-660 was mated into recipient strains carrying pWW0-3006 (carrying HD cloned into pK T230; Fig. 2) and pWW0-3024 (SmaI/HindIII subclone of HD in pK T230; Fig. 2) both of the respective transconjugants were able to grow at the expense of $m$-xylene, although

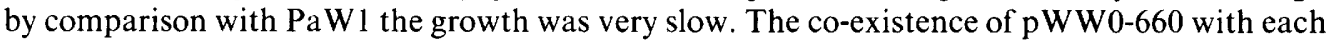
recombinant plasmid was confirmed by isolation of each plasmid separately. Whereas only the large TOL plasmid was isolated by the sucrose gradient method, only the small recombinant plasmids were isolated by the small-scale rapid extraction. Thus it was demonstrated that both plasmids were maintained as independent replicons. Since they shared no sequence homology the possibility of recombination did not arise.

Enzyme assays of PaW820 (pWW0-660, pWW0-3006) showed that the only fully complemented upper operon enzyme was BZDH ( $x y l C$ gene product): its activity was comparable to wild-type PaWl and was inducible by $m$-xylene, whereas BADH $(x y l B)$ levels remained low and were not induced. These results confirmed that both $x y l C$ and the operatorpromoter region (OP1) were located on HD but that $x y l B$ was not. Furthermore, since PaW825 (pWW0-660, pWW0-3024) showed the same phenotype and induction patterns (data not shown) as PaW820, these functions could be more precisely located on the $5.5 \mathrm{kbp} \mathrm{Smal/HindIII}$ fragment in $\mathrm{pWW} 0-3024$.

The uptake of $\mathrm{O}_{2}$ was stimulated by $m$-xylene to a low but detectable level in PaW820 but not in strains carrying either pWW0-660 or pWW0-3006 alone, suggesting a low degree of complementation of the xylene oxidase activity (data not presented).

Enzymes of the lower operon were not induced by $m$-xylene in strains containing only pWW0660 but were induced in PaW820 (Table 2), indicating the presence of a gene on HD which affects the expression of the lower pathway in the presence of $m$-xylene.

Similar results were obtained when the insertion mutant plasmid pWW0-673 was complemented with pWW0-3006 (Table 2), showing that the insertion in OP1 affected the induction by $m$-xylene of both operons, and that this effect was complemented by pWW0-3006: induction of the lower operon enzymes by $m$-toluate was as with PaW1.

\section{Comparison of $m$-xylene and m-methylbenzyl alcohol as inducers of the lower operon}

The inability of $m$-xylene to induce the $x y l D L E G F$ operon in pWW0-660 in spite of the functional presence of both $x y l R$ (as indicated by the induction of BZDH activity on HD) and $x y l S$ on the plasmid is in conflict with the present model for the regulation of the two operons (Worsey et al., 1978). This also applies to pWW0-673 which carries an insert in or close to the OP1 region of the plasmid, and led to the incorrect conclusion for the indistinguishable plasmid pWW0-2001 that the insert was in the $x y l R$ gene which was consequently wrongly located 
Table 2. Enzyme activities in complemented and parental strains of P. putida

Enzyme activities are expressed as milliunits of activity per mg protein; ND, not determined.

\begin{tabular}{|c|c|c|c|c|c|c|c|}
\hline Strain & Plasmid & Inducer & BADH & BZDH & $\mathrm{C} 23 \mathrm{O}$ & $\mathrm{HMSH}$ & HMSD \\
\hline PaWl & $\mathrm{pWW} 0$ & $\begin{array}{l}m \text {-Xylene } \\
m \text {-Toluate } \\
\text { None }\end{array}$ & $\begin{array}{r}580 \\
15 \\
16\end{array}$ & $\begin{array}{r}480 \\
60 \\
8\end{array}$ & $\begin{array}{r}15600 \\
3700 \\
130\end{array}$ & $\begin{array}{r}1000 \\
325 \\
8\end{array}$ & $\begin{array}{r}120 \\
115 \\
25\end{array}$ \\
\hline PaW790 & pWW0-3006 & $\begin{array}{l}m \text {-Xylene } \\
\text { None }\end{array}$ & $\begin{array}{l}44 \\
38\end{array}$ & $\begin{array}{l}12 \\
14\end{array}$ & $\begin{array}{l}<1 \\
<1\end{array}$ & $\begin{array}{l}\text { ND } \\
\text { ND }\end{array}$ & $\begin{array}{l}\text { ND } \\
\text { ND }\end{array}$ \\
\hline PaW660 & pWW0-660 & $\begin{array}{l}m \text {-Xylene } \\
m \text {-Toluate } \\
\text { None }\end{array}$ & $\begin{array}{l}58 \\
50 \\
45\end{array}$ & $\begin{array}{l}30 \\
25 \\
11\end{array}$ & $\begin{array}{r}130 \\
10000 \\
170\end{array}$ & $\begin{array}{r}38 \\
250 \\
10\end{array}$ & $\begin{array}{r}20 \\
130 \\
19\end{array}$ \\
\hline PaW 820 & $\begin{array}{l}\text { pWW0-660, } \\
\text { pWW0-3006 }\end{array}$ & $\begin{array}{l}m \text {-Xylene } \\
\text { None }\end{array}$ & $\begin{array}{l}45 \\
55\end{array}$ & $\begin{array}{r}1100 \\
45\end{array}$ & $\begin{array}{r}18000 \\
150\end{array}$ & $\begin{array}{r}370 \\
5\end{array}$ & $\begin{array}{r}150 \\
16\end{array}$ \\
\hline PaW673 & pWW0-673 & $\begin{array}{l}m \text {-Xylene } \\
m \text {-Toluate } \\
\text { None }\end{array}$ & $\begin{array}{l}15 \\
20 \\
20\end{array}$ & $\begin{array}{l}25 \\
95 \\
10\end{array}$ & $\begin{array}{r}170 \\
7700 \\
230\end{array}$ & $\begin{array}{r}5 \\
220 \\
9\end{array}$ & $\begin{array}{r}20 \\
100 \\
11\end{array}$ \\
\hline PaW796 & $\begin{array}{l}\text { pWW0-673, } \\
\text { pWW0-3006 }\end{array}$ & $\begin{array}{l}m \text {-Xylene } \\
\text { None }\end{array}$ & $\begin{array}{l}40 \\
12\end{array}$ & $\begin{array}{r}380 \\
10\end{array}$ & $\begin{array}{r}9100 \\
170\end{array}$ & $\begin{array}{r}510 \\
10\end{array}$ & $\begin{array}{r}240 \\
15\end{array}$ \\
\hline
\end{tabular}

Table 3. Comparison of the induction of lower operon enzymes by m-xylene and m-methylbenzyl alcohol

Enzyme activities are expressed as milliunits of activity per mg protein.

\begin{tabular}{cclrrr} 
Strain & Plasmid & \multicolumn{1}{c}{ Inducer } & C230 & HMSH & HMSD \\
PaW660 & pWW0-660 & m-Methylbenzyl alcohol & 8900 & 570 & 180 \\
& & $m$-Xylene & 200 & 38 & 20 \\
PaW673 & pWW0-673 & m-Methylbenzyl alcohol & 23300 & 640 & 160 \\
& & $m$-Xylene & 170 & 5 & 20
\end{tabular}

upstream of the $x y l C A B$ operon (Jeenes \& Williams, 1982; Lehrbach et al., 1983). It had been reported to us that similar insertion mutants expressed the genes of the lower operon normally when induced with $m$-methylbenzyl alcohol (K. Timmis, personal communication). This led us to compare the roles of $m$-xylene and $m$-methylbenzyl alcohol as inducers in PaW660 and PaW673. The results (Table 3) show conclusively that their roles as inducers are not equivalent as previously assumed and that whereas $m$-xylene is unable to induce the $x y l D L E G F$ operon, $m$-methylbenzyl alcohol can.

\section{Location of $x y l C$ on fragment $H D$}

The SmaI/HindIII fragment from pWW0-3024 was subcloned to locate the BZDH $(x y l C)$ gene more precisely. The structures of the subclones used are shown in Fig. 2. The plasmids were all maintained in E. coli and assays were done with cell-free extracts made from these strains.

The XG fragment (in pWW0-3002) expressed low levels of BZDH activity [40 munits (mg protein $)^{-1}$ ] despite being in the wrong orientation to allow expression from the kanamycin promoter of the pK T230 vector. It was concluded from this observation that there was a weak promoter upstream of the $x y l C$ gene on the $\mathrm{XG}$ fragment. None of the subclones in which the XG fragment was cut at the BamHI site (pWW0-3026, pWW0-3029) expressed BZDH activity $\left[<1\right.$ munit (mg protein) ${ }^{-1}$ ], suggesting that the BamHI site lay within the structural gene. However, the SalI subclone of XG, pWW0-3027, exhibited high levels of BZDH activity [400 munits (mg protein) ${ }^{-1}$ ]. It was shown that these high levels of expression were due to the tetracycline promoter of the pBR325 vector since reversal of the orientation of the fragment in pWW0-3028 resulted in complete loss of activity. These results show that the entire $x y l C$ gene is located on a single $1.9 \mathrm{kbp} \mathrm{SalI}$ fragment within XG. The end of the gene lies in the 100 bases 
between the Bam HI site and the SalI site close to the unique XbaI site on XG. The start of the gene has not yet been located precisely but lies downstream of the SalI sites at the left-hand end of $\mathrm{XG}$ and therefore at least $1 \mathrm{kbp}$ away from the site identified as OP1. These results are summarized in Fig. 3.

\section{DISCUSSION}

The present work has demonstrated that cloned wild-type DNA from the HD region is able to complement the deletion of the entire upper operon on pWW0-660 and restore the ability to grow on $m$-xylene, albeit slowly. The only gene product which was fully complemented was $x y l C$ and this gene has been subsequently subcloned and located on a $1.9 \mathrm{kbp}$ Sall fragment. Interestingly, although Timmis et al. (1985) have determined the gene order of the operon to be $x y / C A B, x y / C$ is not the product of the open reading-frame found directly after OP1, which Inouye et al. (1984) initially proposed was $x y l A$ and Mermod et al. (1984) identified as $x y l C$; the function of this initial putative polypeptide which is terminated before $x y l C$ is at present under investigation.

The ability of the complemented strains to grow on $m$-xylene requires a functional $x y l A$ gene and this must also be present on HD since on pWW0-660 the gene is entirely deleted and there is no corresponding chromosomal function. The absence of BADH $(x y l B)$ agrees with the map location determined by Inouye et al. (1981 $a)$ and Timmis et al. (1985) to be downstream of the right-hand end of HD. Presumably the ability of the complemented strains to grow on $m$-xylene in the absence of $x y l B$ requires the participation of the chromosomal BADH gene. This may be the cause of their slow growth on $m$-xylene. Alternatively it may be that the complete genetic information for $x y l A$ expression is not present on HD, which would also account for the low stimulation of $\mathrm{O}_{2}$ uptake by $m$-xylene in the complemented strains PaW820 and PaW825. However, we would not wish too much emphasis to be put on conclusions drawn from what is an unsatisfactory method of assaying direct enzyme attack on a hydrocarbon which is likely to have multiple and unrelated effects on cellular respiration.

The most unexpected result from the complementation experiments was that HD restored the induction of the lower pathway operon by growth in the presence of $m$-xylene. Since the generally accepted model for regulation proposed that $m$-xylene could act with the product of $x y l R$ to induce the $x y l D L E G F$ operon (Worsey et al., 1978), the assumption was made that the insertion in pWW0-2001 (indistinguishable from that in pWW0-673) was in the $x y l R$ gene, which was therefore assumed to be upstream of the $x y l C A B$ operon (Jeenes \& Williams, 1982; Lehrbach et al., 1983). This was shown to be incorrect by the later mapping of $x y l R$ at least $35 \mathrm{kbp}$ distant from the insertion site (Franklin et al., 1983). The inability of $m$-xylene to induce $x y l D L E G F$ on the deleted plasmid pWW0-660 reported here casts additional serious doubt on the model. It could be argued that pWW0-660 and pWW0-673 carry additional regulatory mutations but this seems unlikely since both are here shown to carry fully functional $x y l S$ and $x y l R$ genes. $X y l S$ functions normally since $m$-toluate acts as both inducer of $x y l D L E G F$ and a growth substrate for host strains of both plasmids. Furthermore, $x y l R$ must also be present and functional since $x y l C$ is induced by $m$-xylene when HD is present in trans on a recombinant plasmid. The inability of $m$-xylene to induce $x y l D L E G F$ in the presence of a functional $x y l R$ must represent a natural feature of the regulation.

The restoration of $m$-xylene induction of the lower operon by HD must therefore be due to a gene product encoded on HD. We propose that this gene is in fact $x y l A$, the presence of which on HD has been demonstrated by the restoration of the $\mathrm{Mxy}^{+}$phenotype by complementation. This can convert $m$-xylene to $m$-methylbenzyl alcohol and, as we have shown conclusively with $\mathrm{PaW660}$ and PaW673, $m$-methylbenzyl alcohol is not equivalent to $m$-xylene as an inducer and is able to induce $x y l D L E G F$ under conditions where $m$-xylene cannot. The work presented here does not demonstrate whether this induction involves the participation of only the $x y l S$ gene product, with $m$-methylbenzyl alcohol acting as an analogue of $m$-toluate, or whether $x y l R$ gene product is also required. However, the results of Franklin et al. (1983) suggest that functional $x y l R$ and $x y l S$ genes are required for $m$-methylbenzyl alcohol induction of $x y l D L E G F$. 
These results are in conflict with those of Inouye et al. (1983) which showed that cloned $x y l R$ gene could initiate transcription at the cloned operator-promoter region (OP2) of the lower operon. However, their experiments were done using $E$. coli with the genes cloned in high copy number vectors, and induced levels of expression were very low. Our experiments have involved $P$. putida, the natural host for expression of the catabolic functions, and induced levels of expression were of the same orders of magnitude as in wild-type cells.

This work was supported by a grant from Shell Research.

\section{REFERENCES}

Bagdasarian, M., Lurz, R., Ruckert, B., Franklin, F. C. H., Bagdasarian, M. M., Frey, J. \& Timmis, K. N. (1981). Specific purpose cloning vectors. II. Broad host-range, high copy-number RSF1010derived vectors and a host-vector system for gene cloning in Pseudomonas. Gene 16, 237-247.

Bolivar, F. (1978). Construction and characterisation of new cloning vehicles. III. Derivatives of plasmid pBR322 carrying unique EcoRI sites for selection of EcoRI generated recombinant DNA molecules. Gene 4, 121-136.

Franklin, F. C. H. \& Williams, P A. (1980). Construction of a partial diploid for the degradative pathway encoded by the TOL plasmid (pWW0) from Pseudomonas putida $\mathrm{mt}-2$ : evidence for the positive nature of the regulation of $x y / R$ gene. Molecular and General Genetics 177, 321-328.

Franklin, F. C. H., Bagdasarian, M., Bagdasarian, M. M. \& Timmis, K. N. (1981). Molecular and functional analysis of the TOL plasmid $\mathrm{pWW} 0$ from Pseudomonas putida and cloning of genes for the entire regulated aromatic ring meta cleavage pathway. Proceedings of the National Academy of Sciences of the United States of America 78, 7458-7462.

Franklin, F. C. H., Lehrbach, P. R., Lurz, R., Ruckert, B., Bagdasarian, M. \& Timmis, K. N. (1983). Localisation and functional analysis of transposon mutations in regulatory genes of the TOL catabolic pathway. Journal of Bacteriology 154, 676685.

Girvitz, S. C., Bacchetti, S., Rainbow, A. J. \& Graham, F. W. (1980). A rapid and efficient procedure for the purification of DNA from agarose gels. Analytical Biochemistry 106, 492-496.

Guerry, P., Leblanc, D. J. \& Falkow, S. (1973). General method for isolation of plasmid deoxyribonucleic acid. Journal of Bacteriology 116, 1064-1066.

Harayama, S., Lehrbach, P. R. \& Timmis, K. N. (1984). Transposon mutagenesis of meta-cleavage pathway operon genes of the TOL plasmid of Pseudomonas putida mt-2. Journal of Bacteriology 160, 251-255.

Holmes, D. S. \& Quigley, M. (1981). A rapid boiling method for preparation of bacterial plasmids. Analytical Biochemistry 114, 193-197.

INOUYe, S., NaKaZaWA, A. \& NaKaZawa, T. (1981 $a$ ). Molecular cloning of TOL genes $x y l B$ and $x y l E$ in Escherichia coli. Journal of Bacteriology 145, 11431157.

Inouye, S., Nakazawa, A.\& Nakazawa, T. (1981 $b$ ). Molecular cloning of gene $x y / S$ of the TOL plasmid: evidence for the positive regulation of $x y l D E G F$ operon by $x y / S$. Journal of Bacteriology 148, 413-418.
INOUYe, S., NaKaZaWA, A. \& NaKaZAWA, T. (1983). Molecular cloning of regulatory gene $x y l R$ and operator promoter regions of the $x y l A B C$ and $x y l D E G F$ operons of the TOL plasmid. Journal of Bacteriology 155, 1191-1199.

Inouye, S., Ebina, Y., NakaZawa, A. \& Nakazawa, T. (1984). Nucleotide sequence surrounding transcription initiation site of the $x y l A B C$ operon on TOL plasmid of Pseudomonas putida. Proceedings of the National Academy of Sciences of the United States of America 81, 1688-1691.

JEENES, D. J. (1982). The structure and properties of the TOL plasmid $p W W 0$ in a chlorobenzoate-degrading Pseudomonas. PhD thesis, University College of $\mathrm{N}$. Wales.

Jeenes, D. J. \& Williams, P. A. (1982). Excision and integration of degradative pathway genes from TOL plasmid pWW0. Journal of Bacteriology 150, 188191.

Jeenes, D. J., Reineke, W., Knackmuss, H.-J. \& Williams, P. A. (1982). TOL plasmid pWW0 in constructed halobenzoate-degrading Pseudomonas strains: enzyme regulations and DNA structure. Journal of Bacteriology 150, 180-187.

Lehrbach, P. R., Jeenes, D. J. \& Broda, P. (1983). Characterisation by molecular cloning of insertion mutants in TOL catabolic functions. Plasmid 9, 112125.

Maniatis, T., Fritsch, E. F. \& Sambrook, J. (editors) (1982). Molecular Cloning : a Laboratory Manual, pp. 98-148. Cold Spring Harbor, NY: Cold Spring Harbor Laboratory.

Mermod, N., Lehrbach, P. R., Reineke, W. \& TimmIS, K. N. (1984). Transcription of the TOL plasmid toluate catabolic pathway operon of Pseudomonas putida is determined by a pair of co-ordinating and positively regulated overlapping promoters. EMBO Journal 3, (11), 2461-2466.

NaKazawa, T., INouye, S. \& NaKazawa, A. (1980). Physical and functional mapping of RP4-TOL plasmid recombinants: analysis of insertion and deletion mutants. Journal of Bacteriology 144, 222231.

Sala-Trepat, J. M. \& Evans, W. C. (1971). The meta cleavage of catechol by Azotobacter species: 4oxocrotonate pathway. European Journal of Biochemistry 20, 400-413.

Timmis, K. N., Lehrbach, P. R., Harayama, S., Den, R. H., Mermod, N., BAS, S., LePPIK, R., Weightman, A. J., Reineke, W. \& KNaCkmuss, H.-J. (1985). Analysis and manipulation of plasmid encoded pathways for the catabolism of aromatic compounds by soil bacteria. In Plasmids in Bacteria, pp. 
719-739. Edited by D. R. Habinski, S. N. Cohen, D. B. Clewell, D. A. Jackson \& A. Hollaender. New York: Plenum Press.

Wheatcroft, R. \& Williams, P. A. (1981). Rapid methods for the study of both stable and unstable plasmids in Pseudomonas. Journal of General Microbiology 124, 433-437.

Williams, P. A. \& Murray, K. (1974). Metabolism of benzoate and the methylbenzoates by Pseudomonas putida (arvilla) mt-2: evidence for the existence of a TOL plasmid. Journal of Bacteriology 120, 416-423.
Worsey, M. J. \& Williams, P. A. (1975). Metabolism of toluene and xylenes by Pseudomonas putida (artilla) $\mathrm{mt}-2$ : evidence for a new function of the TOL plasmid. Journal of Bacteriology 124, 7-13.

Worsey, M. J., Franklin, F. C. H. \& Williams, P. A. (1978). Regulation of the degradative pathway enzymes coded by the TOL plasmid ( $\mathrm{pWW}$ ) from Pseudomonas putida mt-2. Journal of Bacteriology 134, 757-764. 